\title{
China's Industrial State-owned Enterprises Between Profitability and Bankruptcy
}


This page is intentionally left blank 


\section{Chima's Industrial \\ State-owned Enterprises \\ Between Profitability and Bankruptcy}

\section{Carsten A. Holz}


Published by

World Scientific Publishing Co. Pte. Ltd.

5 Toh Tuck Link, Singapore 596224

USA office: Suite 202, 1060 Main Street, River Edge, NJ 07661

UK office: 57 Shelton Street, Covent Garden, London WC2H 9HE

\section{British Library Cataloguing-in-Publication Data}

A catalogue record for this book is available from the British Library.

\section{CHINA'S INDUSTRIAL STATE-OWNED ENTERPRISES BETWEEN PROFITABILITY AND BANKRUPTCY}

Copyright ( 2003 by World Scientific Publishing Co. Pte. Ltd.

All rights reserved. This book, or parts thereof, may not be reproduced in any form or by any means, electronic or mechanical, including photocopying, recording or any information storage and retrieval system now known or to be invented, without written permission from the Publisher.

For photocopying of material in this volume, please pay a copying fee through the Copyright Clearance Center, Inc., 222 Rosewood Drive, Danvers, MA 01923, USA. In this case permission to photocopy is not required from the publisher.

ISBN $981-238-332-8$

Printed in Singapore. 
To Thomas P. Lyons 
This page is intentionally left blank 


\section{Preface}

The fate of China's industrial state-owned enterprises (SOEs) has occupied the minds of economists inside as well as outside China for the past two decades. The data certainly look grim. Between 1978 and 1997, losses in industrial SOEs rose twentyfold. By 1998, approximately $20 \%$ of all industrial SOEs had partly or fully stopped production. Capacity utilization in more than half of all industrial SOEs was below $60 \%$. One-third of all employees in industrial SOEs had been made redundant. While in 1990 industrial SOEs in only three of the thirty major industrial sectors were running aggregate losses, by 1997 there were aggregate losses in fully 25 of the then 39 sectors. Yet by 2001, the number of industrial sectors in which SOEs were running aggregate losses was down to four.

These facts raise a number of questions. First, why did the profitability of industrial SOEs decline so drastically during the first two decades of China's economic reforms? Did competition drive down profitability, was labor remuneration excessive, or was a high liability-asset ratio to blame? What can we learn about the causes of the decline from industrial SOEs' profit and loss account? Once we know the causes of the decline in industrial SOE profitability over the past more than two decades, what are the implications for industrial SOE profitability in the future?

Second, how do industrial SOEs compare with industrial non-SOEs? Is profitability in industrial non-SOEs so much higher than in industrial SOEs that a change in the ownership form of industrial SOEs is called for? What explains the difference in industrial SOE vs. non-SOE profitability? Are differences in profitability the outcome of continued differential government policies or of systemic deficiencies in SOEs?

Third, are profit rates equal across all industrial SOEs, or do we need to distinguish between specific groups of industrial SOEs, or even individual 
enterprises? Does sector, location, size, or ownership level matter? If profit rates are not equal, why not, and what are the implications of unequal profit rates for industrial SOE reform?

Finally, what has the Chinese government done to improve industrial SOE profitability? In 1998, the central government initiated a three-year SOE reform program. Has it achieved its objectives? Which government reform policies succeeded, and which did not? What are the current impasses in industrial SOE reform, and what are the prospects for their resolution?

Understanding the determinants and characteristics of industrial SOE profitability is important, because profitability matters. Profitability matters, because in the long run it determines the economic viability of an enterprise. Industrial SOE profitability also affects employment, government finances, and the health of the banking system. In as far as low industrial SOE profitability triggers industrial SOE reform measures, which in turn are intricately linked to other reforms ranging from social security reform to financial sector reforms, industrial SOE profitability ultimately has implications for the entire transition process.

Carsten A. Holz December 2002 


\section{Contents}

Preface ......................................................................................... vii

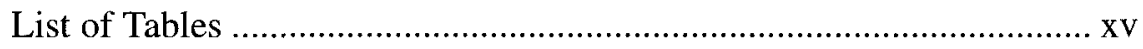

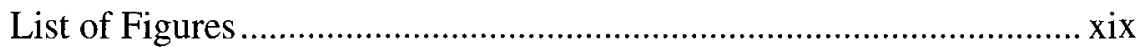

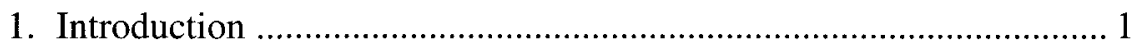

Efficiency May Be an Interesting Concept ... ............................. 2

... But It Is Profitability That Matters ....................................... 3

Industrial SOE Profitability in the Literature ............................... 5

The Issues in This Book ........................................................... 8

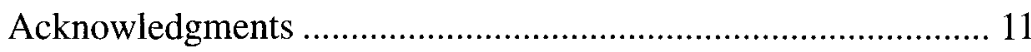

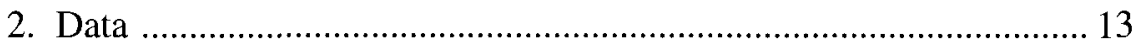

The Directly Reporting Industrial SOEs .................................. 13

Defining the Object of Analysis .......................................... 13

Industrial SOEs in Perspective ........................................... 22

Sectoral and Regional Classification of Industrial SOEs ....... 26

Profit and Profitability Measures .............................................. 31

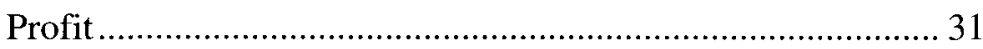

Profitability in the Literature .......................................... 33

Profitability in This Book ................................................. 35

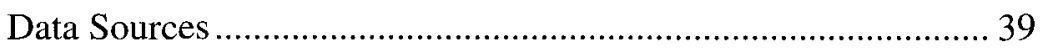

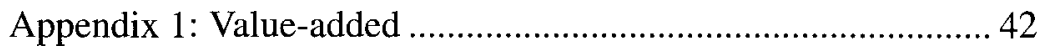

Appendix 2: Depreciation ..................................................... 43

Appendix 3: Labor Remuneration ........................................... 47 


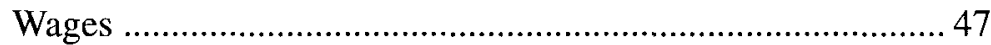

Social Welfare Expenditures for Current Employees ............. 50

Pensions and Social Welfare Expenditures for Retirees ......... 52

\section{Part I Explaining the Reform Period Decline in Industrial} SOE Profitability

3. Tracing the Decline in Industrial SOE Profitability through the Profit and Loss Account ................................................................ 57

Industrial SOE Profitability Trends ...........................................5

Explaining the Decline in Industrial SOE Profitability

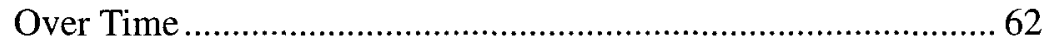

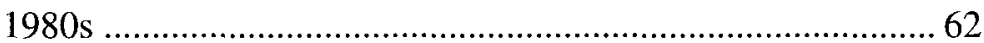

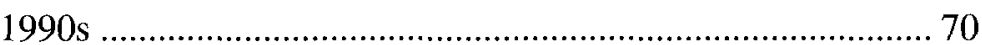

Incentives to Misreport Profit .................................................. 78

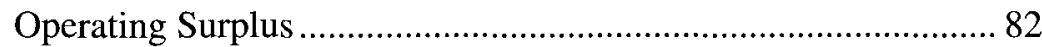

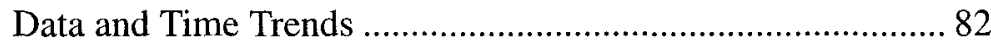

Explaining the Difference in the Time Trends of

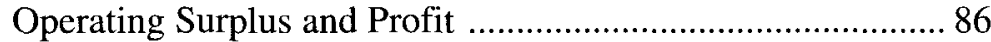

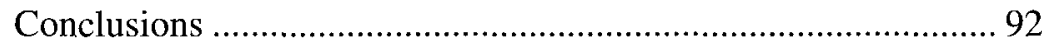

4. The Impact of Competition and Labor Remuneration on Profitability

Competition and Excessive Labor Remuneration Are Not Alternative Hypotheses ......................................................... 98

Intermediate Competition Indicator ..................................... 99

Intermediate Labor Remuneration Indicator ........................ 101

Potential Interaction between Competition and Labor

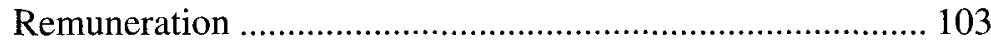

Competition as a Uni-causal Explanation of Profitability ......... 105

Market Share and Profitability ........................................... 106

The Relationship between the Market Share and the

Intermediate Competition Indicator

Excessive Labor Remuneration as an Alternative

Explanation of Profitability 
Analysis Using Nationwide Data ....................................... 115

Analysis Using Provincial-Level Data ................................ 119

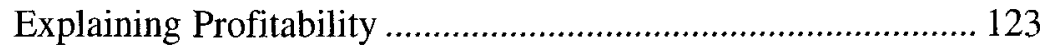

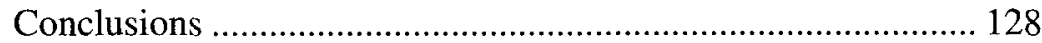

5. The Impact of the Liability-Asset Ratio on Profitability ................ 131

Explaining the Time Trend of the Industrial SOE

Liability-Asset Ratio ............................................................ 134

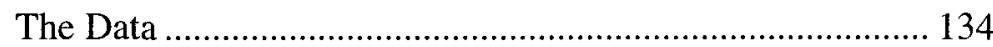

The Rise in the Liability-Asset Ratio During the

Reform Period Reflects the Process of Transition ................ 139

The Liability-Asset Ratio of China's Industrial SOEs

Is Not Excessive in Domestic and International

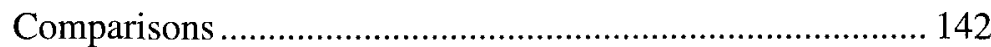

Linking the Liability-Asset Ratio to Profitability .................... 144

Accounting Link between the Liability-Asset Ratio and Profitability ................................................................ 144

Testing the Link Between the Liability-Asset Ratio and

Profitability Measures .................................................... 147

Resolving Potential Endogeneity Problems ........................ 152

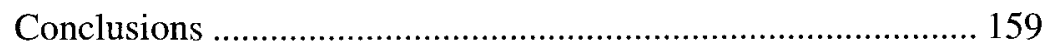

Part II Industrial SOE Profitability in Perspective ..................... 161

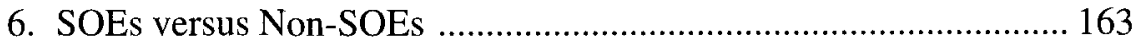

Profitability Patterns of SOEs versus Non-SOEs ...................... 164

SOEs versus the Aggregate of Non-SOEs ........................... 165

Distinguishing among Non-SOEs ......................................... 169

Selection Bias ...................................................................... 174

Explaining the Profitability Gap between Industrial SOEs

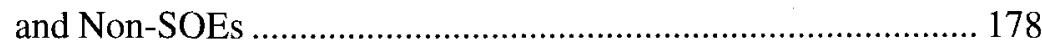

Difference in the Rate of Circulation Taxes ........................ 180

Difference in Capital Intensity ......................................... 186

Costs of a High Level of Capital Intensity ........................ 186

Causes of High SOE Capital Intensity ............................. 190

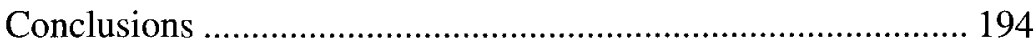




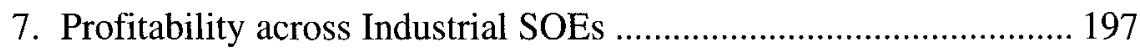

Individual Profitability Patterns ........................................... 200

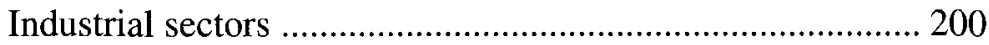

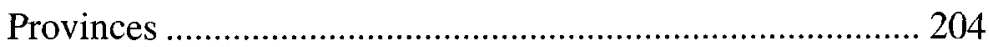

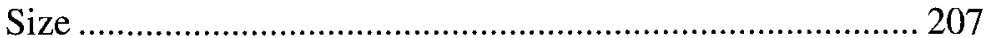

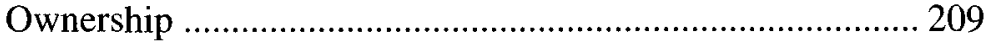

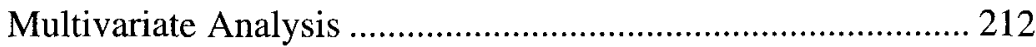

Provincial-Level Industrial SOE Profitability ..................... 213

Within-Province Sectoral Industrial SOE Profitability ......... 220

Sectoral Profitability Patterns ............................................... 221

Sectoral Profitablity Trends ................................................ 223

Polarization Across Sectors ............................................... 226

Implications of Sectoral Industrial SOE Profitability for

Provincial-Level Aggregate Industrial SOE Profitability ..... 233

Polarization Within Sectors ............................................... 237

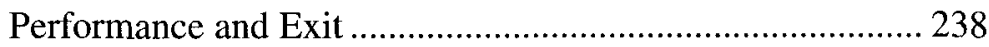

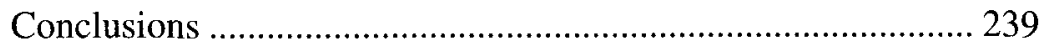

8. Recent Industrial SOE Reform Policies ....................................... 243

The 1998-2000 Industrial SOE Reform Program ..................... 244

The Modern Enterprise System ........................................ 245

Turning Around Large and Medium Industrial SOEs ........... 246

Enlivening Small Industrial Enterprises ............................. 247

Dismissal of Industrial SOE Staff and Workers ................... 249

SOE Equity and Liabilities .......................................... 256

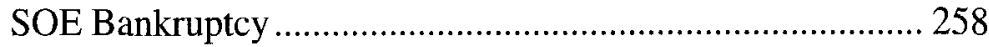

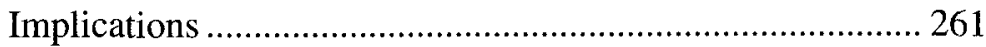

Enhancing Enterprise Management ....................................... 264

Property Rights Reform versus the Modern Enterprise

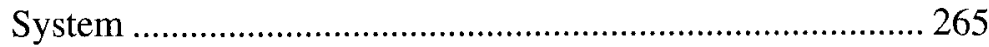

Price Competition .......................................................... 270

Supervision and Personnel Appointment .............................. 273

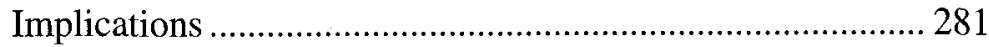

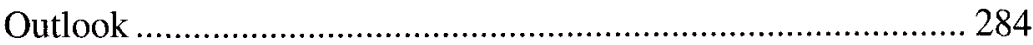




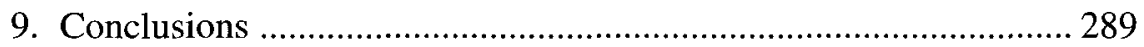

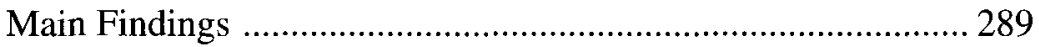

Implications for Privatization .................................................. 295

The Issue of Privatization in the Literature ........................... 296

The Arguments Against Privatization of Large and

Medium Industrial SOEs in China ...................................... 300

Key Issues in Industrial SOE Reform .................................... 304

The Driving Factors Behind Industrial SOE Reform ............. 304

Obstacles to Industrial SOE Profitability .............................. 308

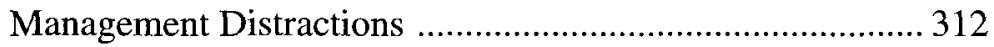

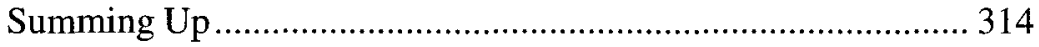

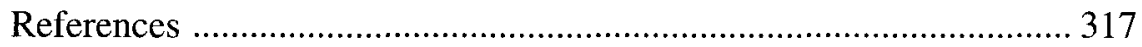

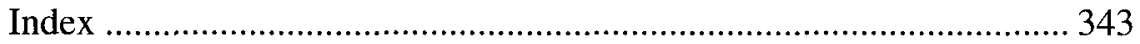


This page is intentionally left blank 


\section{List of Tables}

Table 2.1 Enterprise Categorization (with data for Shaanxi Province, 2000)

Table 2.2 Directly Reporting Industrial Enterprises, 1999 and 2000

Table 2.3 Sectoral Shares in Industrial SOEs' Value-added

Table 2.4 Coverage of Sectoral Data in Provincial Statistical Yearbooks

Table 2.5 Statistical Yearbook Sources for Output, Balance Sheet, and Profit and Loss Account Data

Table 2.6 Estimated Depreciation of Industrial SOEs

Table 2.7 Derivation of the Economy-wide Industrial SOE

Depreciation Rate from Provincial-level Industrial SOE Data, 1992-2000

Table 2.8 Labor Remuneration in Industrial SOEs

Table 3.1 Profitability of Industrial SOEs, 1978-2000

Table 3.2 Composition of Sales Revenue of Industrial SOEs, 1978-2000

Table 3.3 Impact of Changes in Accounting Procedures, Tax System and Depreciation Rules on Profit

Table 3.4 Composition of Value-added in Industrial SOEs, 1978-2000

Table 4.1 Significance Level of Market Share in Explaining Industrial SOE Profitability

Table 4.2 Impact of Market Share on Industrial SOE Intermediate Competition Indicator 
Table 4.3 Correlation Coefficients of Individual Components of Labor Remuneration with the Intermediate Labor Remuneration Indicator or Profitability in Industrial SOEs

Table 4.4 Impact of Labor Remuneration on the Intermediate Labor Remuneration Indicator for Industrial SOEs across Provinces, 1993-1997

Table 4.5 Impact of Labor Remuneration on the Intermediate Labor Remuneration Indicator for Industrial SOEs across Provinces, 1999-2000

Table 4.6 Impact of Competition and Labor Remuneration on Industrial SOE Profit per Unit of Equity across Provinces, 1993-2000

Table 4.7 Impact of Intermediate Competition and Labor 126 Remuneration Indicators on Industrial SOE Profit per Unit of Equity, 1993-2000

Table 4.8 Contribution of Intermediate Competition and Labor Remuneration Indicators to Change in Profitability of Industrial SOEs, 1994-2000

Table 5.1 Liability-Asset Ratios

Table 5.2 Liability-Asset Ratios of Directly Reporting Industrial Enterprises, 1995

Table 5.3 Impact of the Liability-Asset Ratio on Industrial SOE Profitability, 1995

Table 5.4 Impact of the Liability-Asset Ratio on Industrial SOE Profitability, 1993-2000

Table 5.5 Impact of the Liability-Asset Ratio on Industrial 156 SOE Profitability after Accounting for Endogeneity, 1993-2000

Table 6.1 Profitability of Industrial SOEs, 1978-2000

Table 6.2 Profitability of Industrial Non-SOEs, 1978-2000

Table 6.3 Financial Performance of Enterprises with Independent Accounting System at the Township Level and Above, 1995

Table 6.4 Financial Performance of SOEs and Other

Ownership Groups within the Directly Reporting Industrial Enterprises, 1996-2000 
Table 6.5 Profitable vs. Loss-making Industrial SOEs and

Non-SOEs in Five Provinces, 1998-2000

Table 6.6 Sales-related Taxes

Table 6.7 Circulation Taxes and Capital Intensity of SOEs vs.

Non-SOEs across Industrial Sectors

Table 6.8 Capital Intensity

Table 6.9 Adjusting SOE Profitability to Match Non-SOEs'

Capital Intensity and Circulation Tax Rates

Table 7.1 Availability of Data on Industrial SOE Profitability

Table 7.2 Industrial SOE Profitability across Sectors and Provinces, 1986-2000

Table 7.3 Degree of Monopolistic Pricing Power and Industrial SOE Profitability

Table 7.4 Profitability across Size and Ownership Level of Industrial SOEs, 1995

Table 7.5 Correlation Coefficients of Industrial SOE Profitability across Ownership and Size, Selected Provinces 1993-2000

Table 7.6 Patterns of Province-wide Industrial SOE Profit per Unit of Equity, 1993-2000

Table 7.7 Patterns of Province-wide Industrial SOE Losses per Unit of Gross Profit, 1993-2000

Table 7.8 Patterns of Within-Province Industrial SOE Profitability, 1993-2000

Table 7.9 Industrial SOE Sectoral Profitability Clusters, 1993 through 1997

Table 7.10 Sectors with Highest and Lowest Industrial SOE Profitability, 1993-2000

Table 7.11 Performance of Industrial SOEs in Selected Sectors

Table 7.12 Sector-specific Industrial SOE Performance, 1997 and 2000

Table 7.13 Profitable vs. Loss-making Industrial SOEs, Selected Provinces 1998-2000

Table 8.1 Small Industrial SOEs across Provinces, 
This page is intentionally left blank 


\section{List of Figures}

Figure 2.1 Enterprise Coverage in Industry Statistics 15

Figure 2.2 Value-added Shares 22

Figure 2.3 Share of Staff and Workers in Industrial SOEs 25

as Share of Staff and Workers in (i) State-owned Material Production Sectors, and in (ii) All

State-owned Units

Figure 2.4 Profit and Loss Account

Figure 3.1 Profitability of Industrial SOEs, 1978-2000 61

Figure 3.2 Economic Cycles 66

Figure 3.3 Price Indices and Interest Rates 67

Figure 3.4 Industrial SOE Market Share and Price Liberalization 68

Figure 3.5 Operating Surplus and Profit as Shares of 87 Value-added

$\begin{array}{lll}\text { Figure 3.6 Value-added and Profit } & 88\end{array}$

Figure 4.1 Impact of Competition and Labor Remuneration 100 on Profitability

Figure 4.2 Impact of Competition on Industrial SOE Losses per 109 Unit of Gross Profit across Sectors, 1995 vs. 1986

Figure 4.3 Impact of Competition on Industrial SOE Losses Per Unit of Gross Profit across Provinces, 1995 vs. 1986

Figure 5.1 Industrial SOE Liability-Asset Ratios and Profitability 132 across Sectors, 1995

Figure 5.2 Linking the Liability-Asset Ratio to Profitability Measures

Figure 6.1 Non-SOE Profitability Divided by SOE Profitability 